\title{
How not to compete with tigers
}

\begin{abstract}
Australia should take a lesson from its Asia-Pacific neighbours before it undermines its research and higher education infrastructure by slashing budgets for its universities and cutting incentives for industrial research.
\end{abstract}

ONLY last year, the previous Australian government was emphasizing how important it is for that country to develop research links with the rapidly developing economies of Asia. It is ironic, therefore, that the new government's approach to science and higher education (see page 659) could not stand in more unfavourable contrast to others in the Asia-Pacific region.

The 5 per cent cuts in operating funds for universities and the raising of fees for students in science and medicine (see Nature 382, 569; 1996) may not be as bad as had been anticipated a few months ago, but that is small comfort. There is a worldwide trend among young people to turn their backs on careers in research, and what better way to ensure that that trend gets worse in Australia than to impose massive increases in fees for students in science, medicine, engineering and veterinary science while holding those for arts and social sciences at a much lower level?

The cuts and fee increases are being introduced as part of a package of measures to slash more than $A \$ 7$ billion from government spending to try to eliminate a budget deficit without raising taxes. But recent polls show that a majority of Australians oppose squeezing money out of higher education. Instead, they might even accept increases in their comparatively low taxes.

Singapore provides one example of the wholly different approach adopted by Australia's neighbours. Ten years ago, the Singapore government's investment in research and development was negligible. But realizing that it can no longer rely on low-end manufacture of products using cheap labour or trade to survive, the Singapore government has done a remarkable job of pumping money into its universities and new institutes associated with them.

Singapore is not deliberately aiming to support 'blue-sky' research. Rather, it is looking for practical returns for its industry, which it is actively and effectively encouraging to invest in research and development. Nevertheless, its policy over the past five years, led by the National Science and Technology Board which has pumped an extra US $\$ 2$ billion into research, has had a beneficial effect on basic research and science education in Singapore.

The Singapore government, sensitive to the growing trend among young people to turn their backs on science in favour of more financially lucrative careers, is going to great lengths to encourage school-children to pursue careers in research, with science competitions and scholarships to entice the brightest into science and engineering departments in universities. It is also working hard to ensure that there will be research-related jobs for them in local industry when they graduate, by providing incentives to industry to build a research infrastructure. Such efforts make the Australian government's plans to increase fees for science courses while cutting tax incentives for industrial research look short-sighted at best.

The Australian Council of Deans of Education has predicted a serious shortfall of primary and secondary school teachers early next decade because of state education cuts that have already been made. The latest moves seem certain to reduce enrolment in higher-cost science and technology courses at universities, making the teacher shortage even worse in science and mathematics, the very areas that need to be promoted.

The Australian government may respond that it has to grapple with a very different economy from that of Singapore (and other booming economies in Asia). Rapid growth and the high savings rates in Asia make it easier to place strong investments in the universities and research and development infrastructure. Australia, on the other hand, has to struggle with slow growth and a declining savings rate. But, as its neighbours seem to have grasped, weakening the science and technology base will undermine the economy in the longer run.

\section{It's the platform, stupid}

The Republican party in the United States has made the Democrats look strong in science policy.

THE 'party platform' endorsed by Republicans in San Diego, California, last week will have no binding hold on Bob Dole, the party's presidential candidate, who helpfully says that he has not bothered to read it. But the document offers the only available guide to what a Republican Congress and a Dole presidency would actually do after November, given the chance.

The platform's comments on science and technology kick off with an implicit endorsement: "A recent report by the Office of Technology Assessment [OTA] attributes at least half of all economic growth in the United States to advances in technology." What a useful OTA that was before the Republican Congress abolished it last year, in the face of objections from scientists and engineers of every political hue.

The Republicans go on to reaffirm their support for health research and the National Institutes of Health. They say that federal programmes "must emphasise basic research" and call for "private sector funding of applied research" encouraged by unspecified changes in taxation and regulation. But reliance on private-sector funding apparently need not extend to the Department of Defense (DoD) or the National Aeronautics and Space Administration - which between them spend four-fifths of government funds for applied research and development. The platform document accuses Clinton of "decimating" military research and development and "denying crucial resources" to the space programme. The Republicans repeat their long-standing pledge to eliminate the energy department, with the nuclear weapons laboratories going to DoD. The rest of the department would be "farmed out to other departments and offices". An inspiring vision indeed for Fermilab and Brookhaven.

These proposals are a rehash of the two-year-old Contract with America. They indicate that the Republicans have learned very little from their failures since then, and reflect a dearth of serious thinking about science and technology issues on the American right. Furthermore, the Republicans lack staff expertise to match that of their long-entrenched Democrat opponents, and rely too much on advice from industry-funded pseudo- 'think tanks', such as the Heritage Foundation.

The Clinton administration's Office of Science and Technology Policy has been ineffectual at times, but at least it has had some idea of what it is trying to do. This vapid little document suggests that the Republicans have, as yet, no idea at all. 